(c) American Dairy Science Association, 2002.

\title{
The Detection and Avoidance of Lead-Contaminated Herbage by Dairy Cows ${ }^{1}$
}

\author{
S. T. Strojan ${ }^{\star} †$ and C. J. C. Phillips ${ }^{\star}$ \\ ${ }^{*}$ Department of Clinical Veterinary Medicine, \\ University of Cambridge, Cambridge CB3 OES, UK \\ †School of Agricultural and Forest Sciences, \\ University of Wales, Bangor, Gwynedd LL57 2UW, UK
}

\begin{abstract}
Lead from industry, and vehicles in some countries, can contaminate cattle pastures. We determined the concentrations of lead on herbage that cows can detect. Four cows were trained in a four-lane maze to detect an herbage sample that was superficially contaminated with $240 \mathrm{mg} \mathrm{Pb} / \mathrm{kg}$ from three uncontaminated samples, and four were trained to detect an uncontaminated sample from three contaminated samples. $\mathrm{Pb}$ concentrations were reduced until the cows could not discriminate between samples, which occurred at 30 to $60 \mathrm{mg} /$ $\mathrm{kg}$. In a second experiment, 12 cows were allocated to two groups that grazed either pasture with added $\mathrm{Pb}$ $(86 \mathrm{mg} / \mathrm{kg}$ ) or pasture with no added $\mathrm{Pb}$ for $4 \mathrm{wk}$. Lead reduced grazing time and pasture biting rates, leading to an increase in herbage height. Immediately afterwards, these cows were grazed for 4 wk on a mosaic of 18 plots with no added lead, a low Pb level $(67 \mathrm{mg} / \mathrm{kg})$, or a high $\mathrm{Pb}$ level $(102 \mathrm{mg} / \mathrm{kg})$ (Experiment 3). Lead reduced grazing time and pasture biting rate, particularly at the high level. Plots without added $\mathrm{Pb}$ were grazed to the shortest height, and plots treated with $\mathrm{Pb}$ at $102 \mathrm{mg} / \mathrm{kg}$ were tallest. Prior exposure to $\mathrm{Pb}$ increased grazing time, especially on the high $\mathrm{Pb}$ level, and it increased the rate of biting pasture without $\mathrm{Pb}$. To understand these phenomena, herbage samples from Experiments 2 and 3 were incubated in rumen liquor and artificial saliva, and gas production was measured over $48 \mathrm{~h}$. In both experiments, the application of $\mathrm{Pb}$ reduced the rate of gas production or total gas production. It is concluded that cows can detect $\mathrm{Pb}$ on herbage, that it reduces their grazing time and pasture biting rate, and that they prefer to graze pasture without $\mathrm{Pb}$. The aversion to $\mathrm{Pb}$ on pasture, which may be
\end{abstract}

Received March 8, 2002.

Accepted June 11, 2002.

Corresponding author: C. J. C. Phillips; e-mail: cjcp2@cam.ac.uk.

${ }^{1}$ United Kingdom Home Office Licenses were granted for studies on the uptake of heavy metals by the ruminants, and for the extraction of rumen liquor from sheep. due to adverse effects on ruminal digestion, diminishes over time.

(Key words: dairy cows, lead, pasture, grazing)

\section{INTRODUCTION}

Approximately 200 cases of lead poisoning occur annually in British cattle (Livesey, 1994), which is more than any other form of poisoning on farms. Lead toxicity is usually the result of licking lead-based paint, lubricants, and discarded batteries, or grazing near metal works (Haliburton, 1990). There is little uptake of $\mathrm{Pb}$ by plants from the soil, and therefore grazing cattle are most likely to be exposed to $\mathrm{Pb}$ if there is a regular source of airborne contamination (Chumbley and Unwin, 1982). Metal smelters can produce significant amounts of $\mathrm{Pb}$ fallout, resulting in pasture $\mathrm{Pb}$ concentrations of up to $150 \mathrm{mg} / \mathrm{kg}$ within $2 \mathrm{~km}$ of the smelter (Pilgrim and Hughes, 1994). Lead concentrations as high as $45 \mathrm{mg} / \mathrm{kg}$ have been recorded from grass pastures located around tanneries (Kashem and Singh, 1999). The application of municipal sewage sludge can increase pasture lead levels to $80 \mathrm{mg} / \mathrm{kg} \mathrm{DM}$ shortly after application, but $\mathrm{Pb}$ from the sludge does not adhere as well to grass as other heavy metals (Aitken, 1997). In many developing countries, leaded petrol is still used and pastures close to major roads or railways can contain up to $300 \mathrm{mg} \mathrm{Pb} / \mathrm{kg}$ (Motto et al., 1970; Pilgrim and Hughes, 1994).

The effects of $\mathrm{Pb}$ on rumen bacteria are unknown, but it is likely to depend on the $\mathrm{Pb}$ species involved. Inorganic $\mathrm{Pb}$ is not normally adsorbed by either bacteria (Hughes and Poole, 1989) or fungi (Wainwright and Grayston, 1989), and is effectively excluded from cells. However, ionic $\mathrm{Pb}$ has a strong tendency to form organic compounds, such as the lead acetate used in this series of experiments, which are lipid soluble, and the resulting organometallic compounds effectively inhibit growth and respiration of microorganisms (Gadd and Hughes, 1989). The concentration of competing organic acids and chlorophyll in the nutritive medium determines the availability of $\mathrm{Pb}$ to microorganisms, and 
phosphate and carbonate are particularly effective in protecting against $\mathrm{Pb}$ toxicity (Hughes and Poole, 1989).

Mammals can regulate their intake of some metals accurately, particularly essential ones such as sodium (Bell, 1995). This is achieved by specific hungers, which have both learned and genetic components (Bell, 1995; Phillips et al., 1999a). However, some potentially toxic metals, such as thallium, are colorless, tasteless, and odorless, at least to humans (Moore et al., 1993). Some heavy metals, such as zinc and copper, can be detected in food by mammals as they have an inhibitory effect on the sweet taste due to competition for the receptor proteins of the chorda tympani nerve in the tongue (Iwasaki and Sato, 1984).

Lead consumption is associated with pica and anorexia in humans, suggesting that appetite may be modified to facilitate learned avoidance of a contaminated food source (Cohen et al., 1984; Fell, 1984). However, lead poisoning also causes adverse neuropsychological (MRC, 1988) and neurophysiological (IPCS, 1993) effects, particularly in children, which may be responsible for appetite moderation. The limitations of epidemiological studies, such as the difficulty of associating specific toxic effects of $\mathrm{Pb}$ with the sources of contamination, have resulted in many of the effects on farm livestock and humans being extrapolated from laboratory animals. In addition, although there has been considerable research on the effects of $\mathrm{Pb}$ on mammalian physiology, little attention has been paid to the ability of mammals to avoid self-poisoning. A situation can occur in which the animal may become trapped in a vicious cycle where an acquired pica may cause lead poisoning and lead poisoning may cause further disease and depraved appetite.

The possibility that cattle can avoid feed contaminated with $\mathrm{Pb}$ can only be investigated with certainty once their ability to discriminate pasture with different $\mathrm{Pb}$ levels is known, which was the initial subject of this investigation. Further, we investigated whether cattle avoid lead-contaminated pasture, whether avoidance changes with experience of the pasture, and the effects of $\mathrm{Pb}$ on pasture digestion.

\section{MATERIALS AND METHODS}

Field experiments were conducted at the Latvian University of Agriculture dairy farm ( $\left.56^{\circ} 28^{\prime} \mathrm{N}, 22^{\circ} 53^{\prime} \mathrm{E}\right)$ in a 5 ha field of permanent pasture containing mixed species, established on a Podsol with gleying. No fertilizers had been applied for three years prior to the experiments. The sward was assessed for botanical composition at 60 randomly placed quadrants and contained $215 \mathrm{~g} / \mathrm{kg}$ of white clover (Trifolium repens), $203 \mathrm{~g} / \mathrm{kg}$ of smooth meadow grass (Poa pratensis), $138 \mathrm{~g} / \mathrm{kg}$ of

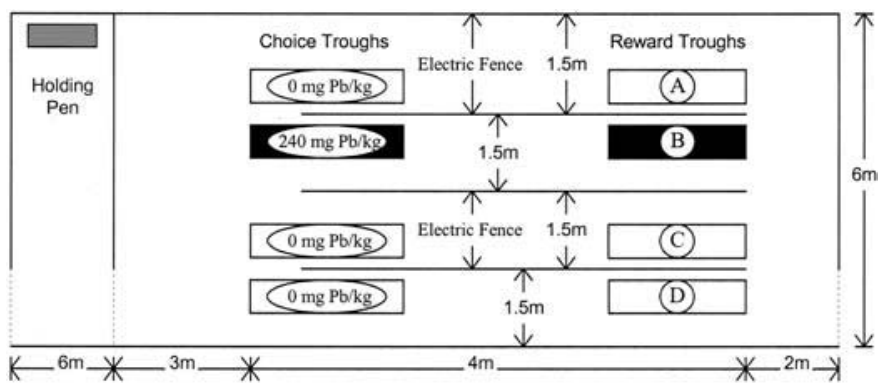

Figure 1. Experimental arena for discrimination tests in Exp. 1, with four lanes each containing a choice trough where the test herbage was provided (in the case illustrated, $240 \mathrm{mg} \mathrm{Pb} / \mathrm{kg}$ ) and a reward trough containing $40 \mathrm{~g}$ concentrate in the same lane (B in this example).

meadow fescue (Festuca Pratensis), $108 \mathrm{~g} / \mathrm{kg}$ of timothy (Phleum pratense), $103 \mathrm{~g} / \mathrm{kg}$ of Canadian thistle (Cirsium arvense), $69 \mathrm{~g} / \mathrm{kg}$ of common yarrow (Archillea milefolium), $66 \mathrm{~g} / \mathrm{kg}$ of Irish daisy (Taraxacum officinale), $57 \mathrm{~g} / \mathrm{kg}$ of cocksfoot (Dactylis glomerata), and 38 $\mathrm{g} / \mathrm{kg}$ of other species. Nulliparous dairy cows of the Latvian Red breed were used for the experiments between 0500 and $1600 \mathrm{~h}$ each day. At night they were tethered indoors and offered $3 \mathrm{~kg}$ of cut herbage per cow and ad libitum access to water. Herbage provided overnight was of similar composition to that offered during the day, but with no added $\mathrm{Pb}$. There were no symptoms of lead toxicity in any cattle, all of which remained in good health throughout the series of experiments.

\section{Exp. 1: The Ability of Cows to Detect $\mathrm{Pb}$ Contamination of Herbage}

Eight cows (mean age 18 mo) were randomly allocated to two groups-four cows trained to select herbage with added $\mathrm{Pb}$ (Lead Selectors) and four cows trained to select herbage without $\mathrm{Pb}$ (No Lead Selectors). Herbage for the experiment was cut daily with a reciprocating blade mower and a solution of $\mathrm{Pb}$ acetate $\left(\left[\mathrm{Pb}\left(\mathrm{CH}_{3} \mathrm{COO}\right)_{2} \cdot 3 \mathrm{H}_{2} \mathrm{O}\right] 99.81 \%\right.$, chlorides $0.0005 \%$, nitrates $0.0002 \%$, copper $0.0005 \%$, iron $0.0001 \%, \mathrm{~K}+\mathrm{Na}$ $+\mathrm{Ca}+\mathrm{Sr} 0.1 \%$, and insolubles $0.005 \%$, Reakhim, Riga, Latvia) was sprayed onto $0.5-\mathrm{kg}$ samples to achieve the required concentration of $\mathrm{Pb}, 240 \mathrm{mg} / \mathrm{kg}$.

The herbage samples were then offered to the cows in a four-lane maze (Figure 1), with each lane containing a choice trough at the start, in which an herbage sample was placed, and a reward trough at the end, which in the case of the correct lane contained a 40-g concentrate reward. Lanes were separated by an electrified wire (12 V). Lead Selectors were offered herbage with $\mathrm{Pb}$ in one of the four lanes and herbage without $\mathrm{Pb}$ in the other 
three; No Lead Selectors were offered a converse setup-herbage without $\mathrm{Pb}$ in one lane and herbage with $\mathrm{Pb}$ in the other three. Each cow was trained 40 times (10 times in each lane) by allowing them to sample the four herbage samples and then leading them through the correct lane. At the end of the training all the cows were consistently selecting the correct lane, and after this, they were tested for their ability to detect $\mathrm{Pb}$ in herbage at five declining $\mathrm{Pb}$ concentrations (240, $120,60,30$, and $15 \mathrm{mg} \mathrm{Pb} / \mathrm{kg}$ herbage), with 40 tests at each level. The position of the correct sample was varied regularly in order to minimize the possibility of the cow learning where the correct choice was located. Cows had access to water and grazing when not undergoing training or tests during the daytime.

Statistical analysis. The statistical significance of the correct choice proportion of the cows was analyzed by chi-squared analysis, assuming a random correct choice proportion of 0.25 (Snedecor and Cochran, 1967).

\section{Exp. 2: The Behavior of Cows Grazed on Pasture With or Without Added Pb}

Twelve cows were allocated to pairs that were similar in live weight and condition. Within pairs, the cows were randomly allocated to two pasture treatments: herbage with no $\mathrm{Pb}$ (-Lead) or herbage with added $\mathrm{Pb}$ (+Lead). The two treatment groups of cows were grazed on two adjacent 0.6-ha areas of pasture, with a 2-m buffer area between the two paddocks. Both groups were provided with water throughout the experiment, which was conducted between August 1 and 28, 1994.

Before the start of the experiment, the herbage in both paddocks was cut to a height of $8 \mathrm{~cm}$ using a disc mower (model E-302, Minisk, Byelorussia). The Pb was sprayed onto the pasture as $65.9 \mathrm{~g}$ of lead acetate in $600 \mathrm{~L}$ of water per paddock, using a boom sprinkler (model OBT-1B, Minisk) connected to a reservoir tank with an automatic mixer. This was done twice weekly and after any periods of rain lasting more than $30 \mathrm{~min}$, with a total of 11 applications during the experiment. The paddock that received no $\mathrm{Pb}$ application was treated with $600 \mathrm{~L}$ of water at the same time as the paddock receiving $\mathrm{Pb}$. Herbage mass and $\mathrm{DM}$ concentration were assessed weekly from 12 samples collected from each paddock, which were dried in a forced-air oven at $80^{\circ} \mathrm{C}$ for $48 \mathrm{~h}$. Mean DM concentrations were $244(\mathrm{SE}=3.8)$ and $248(\mathrm{SE}=4.4) \mathrm{g} \mathrm{DM} / \mathrm{kg}$ fresh weight for the treatments without and with $\mathrm{Pb}$, respectively.

Herbage height was measured using a sward stick (Barthram, 1986) $1 \mathrm{~d}$ prior to the experiment and twice weekly during the experiment, with measurements taken at 10-m intervals in a W-pattern across each treatment paddock. Herbage samples were collected twice weekly to assess herbage mass for the determination of $\mathrm{Pb}$ application rates and for analysis of $\mathrm{Pb}$ concentration by atomic absorption spectrophotometer (Spectrometer AA-800, with GTA-100 Zeeman Varian, Palo Alto, CA), using the procedures of Chiy et al. (1998). Fecal samples were collected from each cow weekly, air-dried in a forced-air oven at $80^{\circ} \mathrm{C}$ for $48 \mathrm{~h}$, hammer-milled through a 1-mm screen, and analyzed for $\mathrm{Pb}$ concentration by the same procedure.

Cow behavior. Each cow was continuously observed from a hide situated between the two pasture areas for 5 min each day, over a 4 -wk period (total length of observation $=140 \mathrm{~min} / \mathrm{cow}$ ). The 1-h daily observation was conducted at stratified times throughout the day. During the observation of each cow, its principal behavior, was classified at 30-s intervals as one of the following: grazing, lying, standing, walking, running, being aggressive (charging or head to head pushing), drinking, grooming (themselves or being groomed by other cows), and mounting (including being mounted).

The rate of biting pasture was recorded for each cow on alternate days as the number of bites during a 90s period of continuous grazing (with no breaks of more than $10 \mathrm{~s}$ ). The distance walked while grazing for $60 \mathrm{~s}$ was recorded twice each week by following each cow with a calibrated wheel at a distance of $4 \mathrm{~m}$ behind its tail.

Statistical analysis. Only the data for walking speed were normally distributed (Anderson-Darling test, Minitab, 1995), and this variable was tested for significance of the treatment effect by one-way ANOVA. The data for sward height, pasture biting rate, grazing, lying, and standing times were not normally distributed, even after a range of transformations, but more than $50 \%$ of the values were integers, so Mood's median test (Minitab, 1995) was used. For all other behaviors, less than $50 \%$ of the observations had integer values, so the chi-squared test of total counts of each behavior for cows in the two treatments was used. However, as this contains repeated measurements over time, the results are only a guide to the true nature of the effect. Replicates for the sward height were 12 individual recordings/treatment at different places of the sward (nested within the repeated measurements over time).

\section{Exp. 3: The Ability of Cows to Avoid Lead-Contaminated Pasture and the Influence of Previous Experience of $\mathrm{Pb}$ on Pasture}

Immediately following Exp. 2, the cows in the + Lead and -Lead treatments were grazed for 4 weeks on a 3.8-ha pasture, which had been divided into 18 plots of $0.2 \mathrm{ha}$, allocated at random to receive no $\mathrm{Pb}$, or a low (60 mg Pb/kg fresh herbage) or high (90 mg Pb/kg fresh 
herbage) level of $\mathrm{Pb}$. Plots were demarcated by colorcoded corner posts, to enable the position of each cow to be identified at a distance, and were separated by 2 $\mathrm{m}$ buffer zones around their perimeter, but there were no perimeter fences to the plots. A drinking trough supplied with clean, potable water was positioned in the middle of each plot. Herbage was trimmed to $8 \mathrm{~cm}$, and the treatments of 0 (Nil), 60 (Low), and 90 (High) $\mathrm{mg} \mathrm{Pb} / \mathrm{kg}$ herbage fresh weight were applied as suspensions of lead acetate twice each week and following periods of rain greater than $30 \mathrm{~min}$, for a total of 16 applications. Application rates were 12 and $18 \mathrm{~g}$ lead acetate in $200 \mathrm{~L}$ of $\mathrm{H}_{2} \mathrm{O}$ in the Low and High treatments, respectively, with the Nil treatment receiving only water. Herbage height was measured as in Exp. 2, but with 12 measurements/plot at 9-m intervals across the plot, and a weekly herbage sample from each plot was analyzed for herbage mass and $\mathrm{Pb}$ concentration.

Cow behavior. The pasture biting rate and distance walked by each cow during grazing was recorded twice weekly by the same methods used in Exp. 2. For a 90min. period twice each week, it was recorded every 5 min whether each cow was grazing, and if so, the plot that it occupied.

Statistical analysis. Sward height was not normally distributed and median values of the Nil, Low, and High treatments were compared by Mood's test. The data for sward DM concentration were transformed by natural logarithms to a normal distribution (as assessed by the Kolmogorov-Smirnov test, which is less susceptible to outliers than the Anderson-Darling test), and analyzed for the significance of Nil, Low, and High treatments by one-way ANOVA. The data for cow walking and pasture biting rates were normally distributed by the Anderson-Darling test and were examined for effects of the Nil, Low, or High treatments and the + or -Lead treatments in Exp. 2 by two-factor ANOVA with interaction term (Minitab, 1995). The proportion of time spent grazing in each treatment was not normally distributed and was analyzed by the chi-squared test as the number of counts in the Nil, Low, and High plots for cows in the + and -Lead treatments in Exp. 2. The risk of social factors influencing the grazing position of some cows was considered, but there is currently no clear evidence of this, and the synchronized nature of their grazing appears to derive mainly from external influences (Phillips, 1998; 2000; Rind and Phillips, 1999).

\section{Measurements of Gas Production using Herbage Samples from Exp. 2 and 3, Incubated in Rumen Liquor and Artificial Saliva}

The digestibility, and therefore the energetic value, of a ruminant feed can be measured in vitro by the amount of gas released when a feed is incubated with ruminal fluid (Menke et al., 1979). Herbage samples were obtained from Exp. 2 and 3 for incubation in rumen liquor and artificial saliva, and gas production was measured over $48 \mathrm{~h}$. Herbage samples were reweighed after drying, and each sample was hammer-milled to pass through a 1-mm screen. It was then added to a buffer medium and rumen liquor in piston pipettes to measure the gas production rate by the method of Menke et al. (1979) and Menke and Steingass (1988).

Preparation of the piston pipettes. In Exp. 2, there were eight control cylinders, without herbage, to quantify gas production from the fermentation of the rumen liquor/buffer solution alone, and 15 replicates of each of the two treatments. In Exp. 3, there were eight control treatments and 10 replicates of each treatment. A homogenous herbage sample of $200 \mathrm{mg}$ DM was added to each syringe pipette and incubated over a 48 -h period in a water bath at $39 \pm 0.5^{\circ} \mathrm{C}$. Calibrated $100-\mathrm{ml}$ glass syringes were graduated at 1/1 (Häberle Labortechnik, Amisgericht Ulm, Germany). Gas production was recorded at intervals of $0,2,4,6,8,10,12,16,24,32$, and $48 \mathrm{~h}$.

In Exp. 3, the $\mathrm{pH}$ of the samples was additionally measured immediately after the end of the experiment, using a Philips PW9421 pH meter (Eindhove, The Netherlands). Prior to the experiment, the $\mathrm{pH}$ of the rumen liquor, artificial saliva, and buffer mixture were 6.94 , 6.83 , and 6.91, respectively.

Rumen liquor. Rumen liquor $(0.5 \mathrm{~L})$ was obtained from three mature Suffolk $\times$ Mule castrated male sheep fitted with rumen cannulas. The sheep were fed a high concentrate diet to stimulate growth of rumen microorganisms, containing $400 \mathrm{~g}$ of concentrate and $600 \mathrm{~g}$ of grass hay per animal daily. Sheep concentrate (CWG Ltd., Stamford, Lincolnshire, UK) contained: $300 \mathrm{~g} / \mathrm{kg}$ of barley, $180 \mathrm{~g} / \mathrm{kg}$ of wheatfeed, $150 \mathrm{~g} / \mathrm{kg}$ of maize gluten feed, $80 \mathrm{~g} / \mathrm{kg}$ of fat supplements, $75 \mathrm{~g} / \mathrm{kg}$ of soy, 75 $\mathrm{g} / \mathrm{kg}$ of rape, $50 \mathrm{~g} / \mathrm{kg}$ of sugar beet pulp, $50 \mathrm{~g} / \mathrm{kg}$ molasses, $30 \mathrm{~g} / \mathrm{kg}$ fishmeal, and $30 \mathrm{~g} / \mathrm{kg}$ vitamins $/$ minerals. The liquor was extracted before morning feeding using a 50-ml syringe, taking care to exclude air, and filtered through a coarse cloth to remove food particles. It was then placed in a beaker in a vacuum flask that had been flushed with $\mathrm{CO}_{2}$.

Statistical analysis. Several nonlinear functions were fitted to the data for gas accumulation (SlideWrite Plus Version 3, Advanced Graphics Software, Encinatas, CA) in an attempt to find a function that would adequately describe the data from the different treatments: exponential, power, 1-site ligand, cumulative, dose response logistic, photosynthesis, $\mathrm{pH}$ activity, sigmoidal, Erfc, Gaussian, logistic peak, log normal, Lorentzian waveform, sine wave, and sine wave ${ }^{2}$. After 
comparison of the regression coefficients and $\mathrm{r}^{2}$ values of the fitted lines, it was evident that only the sigmoidal function adequately modelled the pattern of gas production over time for all treatments, even though the data only occupied part of the fitted curve. Results are only presented for the portion of the curve accompanied by data. The equation of the sigmoidal function takes the form:

$$
\mathrm{y}=\mathrm{a}_{0}+\mathrm{a}_{1} /\left\{1+\exp \left[-\left(\mathrm{x}-\mathrm{a}_{2}\right) / \mathrm{a}_{3}\right]\right\}
$$

where $\mathrm{a}_{0}=$ initial level ( $y$ minimum), $\mathrm{a}_{1}=$ range of transition ( $y$ maximum $-y$ minimum); $\mathrm{a}_{2}=$ middle of transition (at inflection point); and $\mathrm{a}_{3}=$ width of transition.

To aid interpretation of treatment effects, $a_{0}+a_{1}$ were combined for statistical analysis, as this measures total gas production, and the value for $y$ minimum is not presented as it has no biological relevance. All analyses were conducted using the 10th release of the Minitab statistical program (Minitab, 1995).

Distribution and fit-Exp. 2 herbage samples. The distributions of the values for the $\mathrm{a}_{2}, \mathrm{a}_{3}$, and $\mathrm{a}_{0}+$ $a_{1}$ coefficients of the sigmoidal curves of the treatment replicates were normal as indicated by the AndersonDarling test. The coefficients were analyzed statistically for treatment effects using one-way ANOVA. The $\mathrm{r}^{2}$ and adjusted $\mathrm{r}^{2}$ values of the fit of the sigmoidal curves were not normally distributed by the AndersonDarling normality test and transformations of the data did not achieve normal distribution. Therefore the effect of treatment on the adjusted $r^{2}$ values was analyzed using Mood's Median test.

Distribution and fit-Experiment 3 herbage samples. The values for coefficients of the sigmoidal curves of the treatment replicates were tested for normal distribution using the Anderson-Darling test. Only the data for $\mathrm{a}_{0}+\mathrm{a}_{1}$ were normally distributed, but the data for $\mathrm{a}_{3}$ coefficients were transformed to a normal distribution by a natural log conversion. Both of these were analyzed statistically using one-way ANOVA. The $\mathrm{a}_{2}$ coefficient values were analyzed statistically using the Mood's Median test.

The adjusted $r^{2}$ values of the fit of the sigmoidal curves of the treatment replicates were not normally distributed and transformations did not alter this, therefore they were analysed by Mood's Median test. The $\mathrm{pH}$ values were normally distributed by the Anderson-Darling Test (Minitab, 1995) and were therefore analyzed by one-way ANOVA.

\section{RESULTS}

\section{Exp. 1}

The cows that were trained to detect herbage without $\mathrm{Pb}$ (No Lead Selectors) were able to select the correct

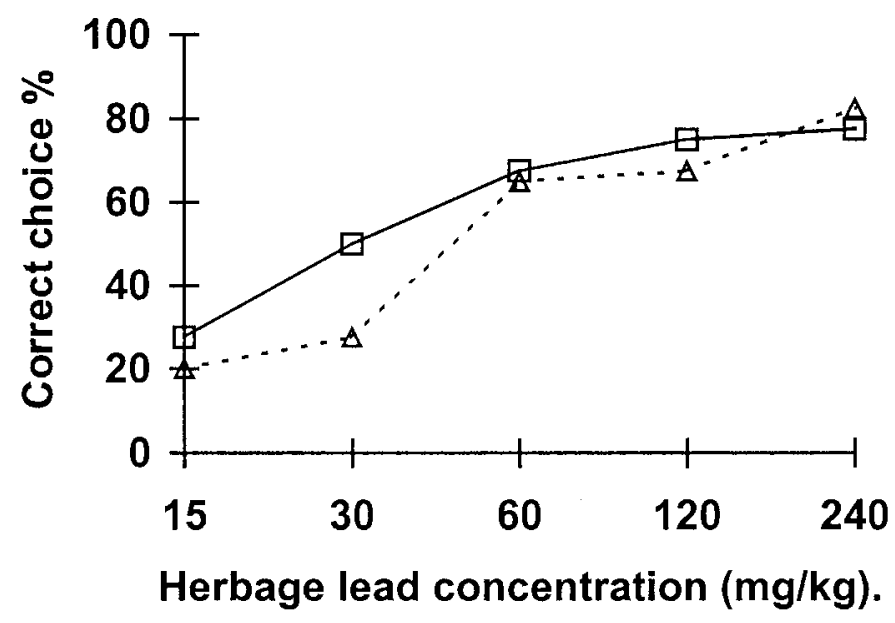

Figure 2. The correct choice proportion for cows either selecting herbage with $(-\square-)$ or without $(--\triangle--)$ lead in Exp. 1. Choices that were significantly different from chance selection are indicated $(P<0.001)$.

lane when the herbage with $\mathrm{Pb}$ contained $30 \mathrm{mgPb} / \mathrm{kg}$ herbage or more $(P<0.001)$ (Figure 2$)$. They were not able to detect the herbage without $\mathrm{Pb}$ at a concentration of $15 \mathrm{mg} \mathrm{Pb} / \mathrm{kg}$ fresh weight $(P>0.1)$. The cows selecting herbage with $\mathrm{Pb}$ were able to select the correct herbage when the $\mathrm{Pb}$ concentration was $60 \mathrm{mg} / \mathrm{kg}$ fresh weight or greater $(P<0.001)$, but not herbage with 15 or 30 $\mathrm{mg} \mathrm{Pb} / \mathrm{kg}$ fresh weight $(P>0.1)$.

\section{Exp. 2}

Compared with cows on the +Lead treatment, the cows on the-Lead treatment grazed for longer and had faster biting rates, leading to reduced herbage height in this treatment (Table 1 ). The + Lead cows tended to

Table 1. The behavior of cows grazed on pasture with (+Lead) or without (-Lead) applied lead in Exp. 2.

\begin{tabular}{lccc}
\hline & \multicolumn{2}{c}{ Treatment } & \\
\cline { 2 - 3 } & -Lead & +Lead & $P$ \\
\hline Grazing, \% of total time & 40 & 20 & 0.006 \\
Biting rate, no./min & 62 & 58 & 0.004 \\
Walking speed, m/min & 2.99 & 2.95 & 0.66 \\
Herbage height, cm & 8.30 & 7.99 & 0.03 \\
Standing, \% of total time & 15 & 29 & $<0.001$ \\
Lying, \% of total time & 30 & 33 & $\mathrm{NS}^{2}$ \\
Aggression, \% of total time & 1.4 & 0.54 & $<0.01$ \\
Grooming, \% total time & 1.3 & 2.4 & $<0.05$ \\
Mounting, \% total time & 0.77 & 0.36 & $<0.1$ \\
Running, \% total time & 0.65 & 0.24 & $<0.1$ \\
Walking, \% total time & 4.6 & 5.2 & $\mathrm{NS}$ \\
Drinking, \% total time & 3.1 & 4.1 & $\mathrm{NS}$ \\
\hline
\end{tabular}

${ }^{1} \mathrm{SE}$ of the difference between the two means $=0.244$.

${ }^{2} \mathrm{NS}=$ not significant. 
Table 2. The effects of lead application to pasture $(\mathrm{Nil}=\mathrm{N}$, Low $=\mathrm{L}$, or High $=\mathrm{H})$, experience of lead-contaminated pasture $(+/-\mathrm{Lead})$, and the interaction between the two (Int.) on cow grazing behavior in Exp. 3.

\begin{tabular}{|c|c|c|c|c|c|c|c|c|c|c|c|c|}
\hline & \multicolumn{6}{|c|}{ Treatment } & & & & \multicolumn{3}{|c|}{$P$} \\
\hline & + Lead & -Lead & +Lead & -Lead & +Lead & -Lead & $\mathrm{N} / \mathrm{L} / \mathrm{H}$ & +/- Lead & Int. & $\mathrm{N} / \mathrm{L} / \mathrm{H}$ & +/-Lead & +/-Lead \\
\hline Grazing time, $\%$ of total & 15.3 & 12.2 & 5.4 & 5.2 & 4.7 & 2.1 & & & & 0.002 & $<0.001$ & 0.08 \\
\hline Biting rate, bite/min & 61.5 & 56.6 & 57.0 & 58.7 & 55.2 & 53.9 & 1.23 & 1.74 & 1.74 & $<0.001$ & 0.15 & 0.04 \\
\hline Walking rate, $\mathrm{m} / \mathrm{min}$ & 2.99 & 3.06 & 2.98 & 2.89 & 2.70 & 2.59 & 0.089 & 0.126 & 0.126 & $<0.001$ & 0.56 & 0.55 \\
\hline
\end{tabular}

${ }^{1} \mathrm{SE}$ of the difference between two means.

be less active, with less time spent being aggressive, running, and mounting and more time spent grooming and standing.

Mean $\mathrm{Pb}$ concentrations in the herbage samples with and without added $\mathrm{Pb}$ were $347(\mathrm{SE}=41.5)$ and $2.5(\mathrm{SE}$ $=0.38) \mathrm{mg} / \mathrm{kg} \mathrm{DM}$, or 86 and $0.62 \mathrm{mg} / \mathrm{kg}$ fresh weight, respectively. The concentrations of other elements in herbage were not significantly $(P<0.1)$ affected by $\mathrm{Pb}$ application (mean concentrations in $\mathrm{mg} / \mathrm{kg} \mathrm{DM}$ were: 19,432 of Ca, 3492 of $\mathrm{K}, 3332$ of $\mathrm{Mg}, 91$ of $\mathrm{Na}, 123$ of $\mathrm{Al}, 3492$ of $\mathrm{P}, 0.052$ of $\mathrm{Cd}, 7.03$ of $\mathrm{Cu}, 27.4$ of $\mathrm{Zn}, 1.10$ of Mo, 36.5 of Mn, 12.7 of B, 0.73 of Co, 0.89 of Ni, 207 of $\mathrm{Fe}$, and $0.64 \mathrm{Cr}$ ). Mean $\mathrm{Pb}$ concentrations in the feces of cows in the +Lead and -Lead treatments were $54.5(\mathrm{SE}=4.28)$ and $2.6(\mathrm{SE}=0.57) \mathrm{mg} / \mathrm{kg} \mathrm{DM}$.

\section{Exp. 3}

Cows spent the greatest amount of time grazing the Nil-lead treatment, and the least amount of time on the High-lead treatment, with the Medium-lead treatment being intermediate (Table 2). The cows that had previously been exposed to lead-contaminated pasture in Exp. 2 spent longer grazing than those that had not, particularly in the High treatment. Pasture biting rate was fastest in the Nil treatment, lowest in the High treatment, with the Medium treatment intermediate. Previous exposure to $\mathrm{Pb}$ increased the rate of biting pasture, but only in the Nil treatment. The walking speed was fastest for cows in the Nil treatment, slowest in the High treatment, and intermediate in the Low treatment. Previous exposure to $\mathrm{Pb}$ did not affect the cows' walking speed.

The Nil swards were the shortest and the High swards were the tallest, with the Medium swards intermediate (Table 3 ). There was no effect of $\mathrm{Pb}$ application on herbage $\mathrm{DM}$ concentration. The mean $\mathrm{Pb}$ concentrations were $10.4(\mathrm{SE}=3.61), 304(\mathrm{SE}=20.1)$, and 462 $(\mathrm{SE}=38.0) \mathrm{mg} / \mathrm{kg} \mathrm{DM}$ or $2.2,67.2$, and $102.1 \mathrm{mg} / \mathrm{kg}$ fresh weight for the Nil, Low, and Medium swards, respectively. The concentrations of other elements in herbage were not significantly $(P<0.1)$ affected by $\mathrm{Pb}$ application (mean concentrations in $\mathrm{mg} / \mathrm{kg} \mathrm{DM}$ were: 44,107 of Ca, 28,253 of K, 2347 of $\mathrm{Mg}, 170$ of Na, 172 of Al, 4495 of $\mathrm{P}, 0.068$ of $\mathrm{Cd}, 3.46$ of $\mathrm{Cu}, 30.5$ of $\mathrm{Zn}, 1.05$ of Mo, 35.85 of $\mathrm{Mn}, 4.49$ of $\mathrm{B}, 0.89$ of $\mathrm{Co}, 0.49$ of $\mathrm{Ni}$, 410 of $\mathrm{Fe}$, and $0.82 \mathrm{Cr}$ ).

\section{Gas Production from Herbage in Exp. 2 and 3}

The portions of the sigmoidal curves of the mean gas production that are supported by data are presented in Figures 3 and 4 for Exp. 2 and 3, respectively. In Exp. $2, \mathrm{~Pb}$ increased the width of the transition (Table 4), indicating a slower rate of gas production up to the plateau. It also reduced the total gas production. There was no difference between the goodness of fit of the curves for the two treatments, as indicated by the adjusted $\mathrm{r}^{2}$ values. In Exp. 3, the application of $\mathrm{Pb}$ delayed the point of inflection, demonstrating a much slower start to the fermentation (Figure 4). The lag phase in both experiments was rapid, which may have been due to the grinding of the samples before fermentation. The reduced width of the transition phase in the Exp. 3 treatments with $\mathrm{Pb}$ (Table 5) reflected the fact that the initial growth phase was included in treatments Low and High, but in the Nil treatment, it was estimated to occur before data collection began (i.e. the negative part of the graph). The effects of $\mathrm{Pb}$ were the same for the Low and High levels of applied $\mathrm{Pb}$. The rate of gas production continued to be reduced by $\mathrm{Pb}$ up until $32 \mathrm{~h}$, but $\mathrm{Pb}$ did not significantly reduce total gas production.

The adjusted $\mathrm{r}^{2}$ was least for the High treatment in Exp. 3 (Table 5), but all $\mathrm{r}^{2}$ values were sufficiently high to allow confidence in the fitted lines. There were no effects of treatment on the final $\mathrm{pH}$.

\section{DISCUSSION}

The first experiment demonstrated that cattle are able to detect $\mathrm{Pb}$ on herbage at concentrations commonly found in polluted regions-in particular, close to major roads and around metal smelters. The cattle also reduced the time spent grazing and the rate of biting 
Table 3. The effects of lead application to pasture (Nil, Medium, or High) on sward height and DM concentration in Exp. 3.

\begin{tabular}{lccccc}
\hline & \multicolumn{4}{c}{ Treatment } & \\
\cline { 2 - 4 } & Nil & Medium & High & SED $^{1}$ & $P$ \\
\hline Sward height, cm & 8.1 & 8.3 & 8.4 & $\ldots$ & $<0.001$ \\
$\begin{array}{l}\text { Herbage DM concentration } \\
\text { log g/kg DM }\end{array}$ & 3.01 & 3.05 & 3.08 & 0.11 & 0.35 \\
g/kg DM & 207 & 214 & 221 & & \\
\hline
\end{tabular}

${ }^{1} \mathrm{SE}$ of the difference between two means.

pasture when grazing lead-contaminated pasture. These responses could be due to adverse effects of the $\mathrm{Pb}$ on the acceptability of herbage, but could also be due to the adverse effects on digestion observed when gas production was measured. A similar reduction in gas production rate was recorded for the Low and High treatments in Exp. 3, yet a greater effect of the high $\mathrm{Pb}$ treatment was apparent on grazing behavior. It is possible that by selective grazing, the cows were able to reduce their $\mathrm{Pb}$ intake to levels where there was a positive dose:response relationship. Reduced biting rate and walking speed were evident as $\mathrm{Pb}$ contamination increased in Exp. 3, providing evidence for selective grazing. The inverse relationship between the $\mathrm{Pb}$ level of the pasture and the walking rates may reflect more selective grazing with $\mathrm{Pb}$. Previous research has demonstrated that cattle walk faster when grazing pastures that have improved nutritional composition (Phillips et al., 1999b); in this case, pasture that had received sodium fertilizer. The general reduction in activity of cows

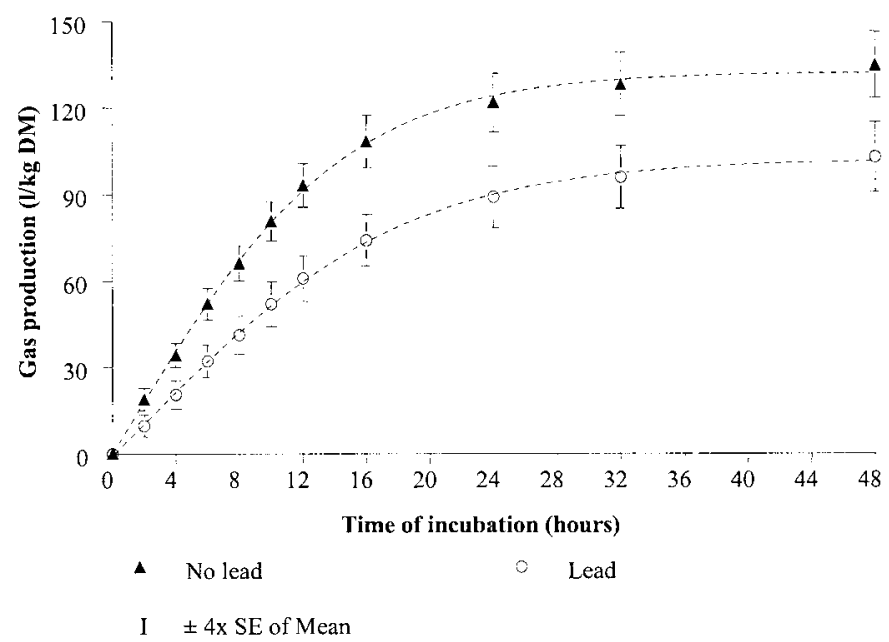

Figure 3. Fitted curves modeling mean gas production data from herbage treatments used in Exp. 2. Equation of fitted sigmoidal curves: $\mathrm{y}=\mathrm{a}_{0}+\mathrm{a}_{1} /\left\{1+\exp \left[-\left(\mathrm{x}-\mathrm{a}_{2}\right) / \mathrm{a}_{3}\right]\right\}$. grazing the lead-contaminated pastures in Exp. 2 may be symptomatic of subclinical effects of the $\mathrm{Pb}$ on the health of the cattle.

Selective grazing may be possible for cattle grazing close to an adjacent road, although Ward et al. (1978) have shown that sheep, which are more selective grazers than cattle, do have elevated blood $\mathrm{Pb}$ concentrations when grazed close to a major road. The opportunity for selection should be taken into account when setting the maximum tolerable dietary concentration, which is $30 \mathrm{mg} / \mathrm{kg}$ for cattle according to the NRC (1980). The limit is more appropriate for cattle fed a homogenous diet from which they cannot select less polluted material. This research suggests that cattle exposed over several weeks may not lose the ability to reduce the consumption of $\mathrm{Pb}$ through selective grazing

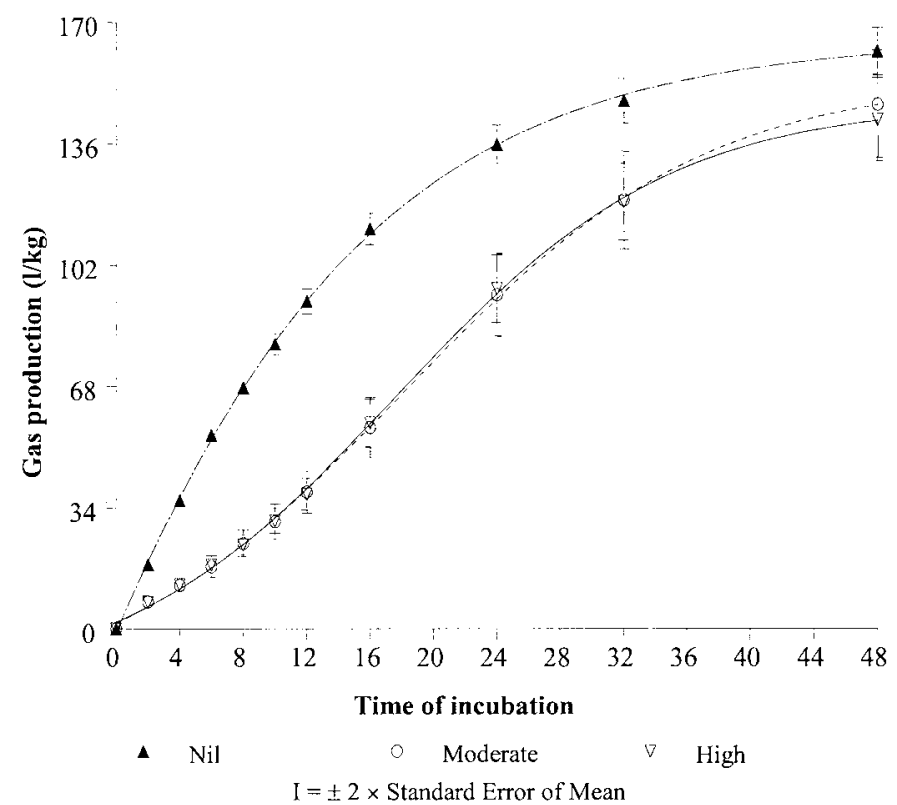

Figure 4. Fitted curves modeling mean gas production data from herbage treatments used in Exp. 3. Equation of fitted sigmoidal curves: $\mathrm{y}=\mathrm{a}_{0}+\mathrm{a}_{1} /\left\{1+\exp \left[-\left(\mathrm{x}-\mathrm{a}_{2}\right) / \mathrm{a}_{3}\right]\right\}$. 
Table 4. The coefficients of the sigmoidal functions fitted to the gas output from pasture with added lead (+Lead) or no lead (-Lead) in Exp 2.

\begin{tabular}{lcccc}
\hline & \multicolumn{3}{c}{ Treatment } & \\
\cline { 2 - 4 } Item $^{1}$ & -Lead & +Lead & SED $^{2}$ & $P$ \\
\hline $\mathrm{a}_{2}$ & 0.90 & 1.62 & 0.902 & 0.43 \\
$\mathrm{a}_{3}$ & 6.8 & 8.4 & 0.27 & $<0.001$ \\
$\mathrm{a}_{0}+\mathrm{a}_{1}$ & 132 & 102 & 4.2 & 0.001 \\
Adjusted $\mathrm{r}^{2}$ & 0.998 & 0.998 & & 0.27 \\
\hline${ }^{1} \mathrm{a}_{0}+\mathrm{a}_{1}=$ total gas production, $\mathrm{a}_{2}=$ middle of transition (inflection point), $\mathrm{a}_{3}$ = width of transition. \\
${ }^{2} \mathrm{SE}$ of the difference between two means.
\end{tabular}

because walking speed and biting rate in the Medium and High $\mathrm{Pb}$ treatments of Exp. 3 were not affected by previous exposure in Exp. 2. The increase in biting rate of cows that had been exposed to $\mathrm{Pb}$ when they grazed the Nil pasture may have been a rebound effect after a month with only pasture with added $\mathrm{Pb}$ to consume.

The increase in grazing time with previous $\mathrm{Pb}$ exposure suggests that the responses are modified over time. Cattle may learn to be more selective without a reduction in biting rate and walking rate. Alternatively, rumen microorganisms may adapt to the adverse effects of increased $\mathrm{Pb}$ intake, but recent research (Osman and Phillips, unpublished data) has not provided any evidence of this. The fact that cattle spend less time grazing pasture with added $\mathrm{Pb}$, both with (Exp. 3) and without (Exp. 2) an alternative sward, suggests that animal performance will be adversely affected under such circumstances.

The increase in the lag phase of gas production in Exp. 3 supports observations by Morozzi et al. (1982) that this is the usual response of bacteria to toxic metals. During this period, the cells have reduced viability since some fail to overcome the toxic challenge. Total gas production would not be relevant for most productive ruminants since the partially digested solids exit the rumen after approximately 12 to $20 \mathrm{~h}$ (AFRC, 1993). For ruminants at maintenance, it is estimated that they might exit after $50 \mathrm{~h}$, in which case the nutritive value of herbage would be less affected by the $\mathrm{Pb}$ than if it were to leave earlier. The difference in the effects of $\mathrm{Pb}$ on the total gas production in the two experiments may be due to the different $\mathrm{Pb}$ levels in the control herbages, 2.53 and $10.4 \mathrm{mg} \mathrm{Pb} / \mathrm{kg} \mathrm{DM}$ in Exp. 1 and 2, respectively. It is possible that any level of $\mathrm{Pb}$ above about 5 $\mathrm{mg} / \mathrm{kg}$ DM reduces total gas production by a similar amount. The absence of any effect of $\mathrm{Pb}$ on the $\mathrm{pH}$ of the incubation medium is reassuring, since the availability of $\mathrm{Pb}$ to microorganisms, for example the mycelium of Penicillium digitatum (Collins and Stotsky, 1989), is highly $\mathrm{pH}$ dependent. This gives confidence that the effects were due to $\mathrm{Pb}$ per se, rather than changes in VFA production and hence the $\mathrm{pH}$ of the media. It also suggests that a similar endpoint had been reached in the three treatments, confirming this inference from the similar total gas production levels.

The interaction of $\mathrm{Pb}$ with other elements, such as $\mathrm{Fe}$, cannot be ruled out. For example, the depletion of phosphate by precipitation as $\mathrm{Pb}_{3}\left(\mathrm{PO}_{4}\right)$ may have limited $\mathrm{P}$ availability. Also the adverse effect of $\mathrm{Pb}$ on herbage digestion could be temporary, since resistance may develop in the rumen bacteria (Bocca et al., 1993). However, the results provide a possible mechanism for cattle to avoid pasture with added $\mathrm{Pb}$ in Exp. 3, since they may have associated the taste of $\mathrm{Pb}$ on the pasture with reduced feed digestibility.

\section{CONCLUSIONS}

The experiments demonstrate that cattle can detect $\mathrm{Pb}$ on herbage when the concentration is 30 to $60 \mathrm{mg} /$ $\mathrm{kg}$ or greater. High $\mathrm{Pb}$ concentrations were shown to reduce grazing time and pasture biting rate by cattle, but prior exposure to $\mathrm{Pb}$ reduced adverse effects of $\mathrm{Pb}$ on grazing time. The addition of $\mathrm{Pb}$ to pasture reduced the rate of digestion, manifest either as a protracted lag phase of microbial growth and a slower growth to a plateau, or as a reduced plateau. A protracted lag phase would reduce the value of herbage for productive ruminant stock, but in the case of reduced total microbial output, only stock at maintenance are likely to be affected because of their low rumen outflow rate.

\section{ACKNOWLEDGMENTS}

The authors are grateful to U. Ositis of the Latvian University of Agriculture for provision of field facilities and to E. Barrado of the Department of Analytical Chemistry at the University of Valladolid, Spain, for element analyses. This work was part of EU Copernicus project CT93-0106 and EU Tempus project JEP 610994.

\section{REFERENCES}

Agricultural and Food Research Council. 1993. Page 25 in Energy and Protein Requirements of Ruminants. CAB International, Wallingford. 
Table 5. The coefficients of the sigmoidal functions fitted to the gas output from pasture with Nil, Low, or High added lead in Exp. 3.

\begin{tabular}{|c|c|c|c|c|c|}
\hline \multirow[b]{2}{*}{ Item $^{1}$} & \multicolumn{3}{|c|}{ Treatment } & \multirow[b]{2}{*}{$\mathrm{SED}^{2}$} & \multirow[b]{2}{*}{ Probability } \\
\hline & Nil & Low & High & & \\
\hline $\mathrm{a}_{2}$, inflection point & 12.8 & 18.4 & 17.5 & & $<0.001$ \\
\hline $\mathrm{a}_{3}$, width of transition & 2.50 & 2.25 & 2.16 & 0.035 & $<0.001$ \\
\hline $\mathrm{a}_{0}+\mathrm{a}_{1}$, total gas production & 165 & 154 & 147 & 8.36 & 0.12 \\
\hline Adjusted $\mathrm{r}^{2}$ & 0.9993 & 0.9994 & 0.9989 & & 0.02 \\
\hline Final $\mathrm{pH}$ & 6.81 & 6.83 & 6.82 & 0.009 & 0.15 \\
\hline
\end{tabular}

${ }^{1} a_{0}+a_{1}=$ total gas production, $a_{2}=$ middle of transition (inflection point), $a_{3}=$ width of transition.

${ }^{2} \mathrm{SEr}$ of the difference between two means.

Aitken, M. N. 1997. Short-term leaf surface adhesion of heavy metals following application of sewage sludge to grassland. Grass Forage Sci. 52:73-85.

Barthram, G. T. 1986. Experimental techniques: The HFRO sward stick. Pages 29-30 in Biennial Report, Hill Farming Research Organisation, 1984-85. HFRO, Edinburgh, UK.

Bell, F. R. 1995. Perception of sodium and sodium appetite in farm animals. Pages 82-90 in Sodium in Agriculture. C. J. C. Phillips and P. C. Chiy, ed. Chalcombe Publications, Canterbury, UK.

Bocca S., E. M. Vermeulen, and M. B. Wachsman. 1993. Multiple resistance to heavy metals and antibiotics in bacteria isolated from the Riachuelo. Rev. Argent. Microbiol. 25:136-143.

Chiy, P. C., M. de la Fuente, E. Barrado, M. Vega, and C. J. C. Phillips. 1998. The determination of mineral balances in sheep offered feed with added cadmium and zinc. Fresenius' J. Anal. Chem. 361:343-348.

Chumbley, C. G., and R. J. Unwin. 1982. Cadmium and Pb content of vegetable crops grown on land with a history of sewage sludge application. Environ. Poll. (Ser. B)4:231-237.

Cohen, D. J., W. T. Johnson and B. K. Capurulo. 1984. Pica and elevated blood $\mathrm{Pb}$ levels in autistic and atypical children. Am. J. Dis. Child. 130:47-48.

Collins, Y. E., and G. Stotsky. 1989. Factors affecting the toxicity of heavy metals to microbes. Pages 1-30 in Metal Ions and Bacteria. T. J. Beveridge and R. J. Doyle, ed. John Wiley \& Sons, New York.

Fell, G. S. 1984. Lead toxicity: Problems of definition and laboratory evaluation. Ann. Clin. Biochem. 21:435-460.

Gadd, G. M., and M. N. Hughes, 1989. Metal mimicry and metal limitation in studies of metal-microbe interactions. Pages 1-18 in Metal-Microbe Interactions. R. K. Poole and G. M. Gadd, ed. IRL Press, Oxford, UK.

Haliburton, J. C. 1990. Lead poisoning identified as a major cause of illness. Feedstuffs 62:31.

Hughes M. N. and R. K. Poole. 1989. Metals and Micro-organisms. Chapman and Hall, London, UK.

International Programme on Chemical Safety (IPCS). 1993. Collective views of a task group of the IPCS on inorganic lead. World Health Organisation, Geneva, Switzerland.

Iwasaki, K., and M. Sato. 1984. Inhibitory effects of some heavy metal ions on taste nerve responses in mice. Jap. J. Physiol. 34:907918 (Abstr.).

Kashem, M. A., and B. R. Singh. 1999. Heavy metal contamination of soil and vegetation in the vicinity of industries in Bangladesh. Water Air Soil Pollut. 115:347-361.

Livesey, C. T. 1994. Contamination of animal feeds: A review of principal causes, detection, investigation and control of toxic contaminants. Pages 25-37 in Pollution in Livestock Production Systems I. A. Dewi, R. F. E. Axford, and H. Omed, ed. CAB International, Wallingford, UK.
Medical Research Council. 1988. The neurophysiological effects of lead in children, a review of research, 1984-1988. Medical Research Council, UK.

Menke K. H., L. Raab, A. Salewski, H. Steingass, D. Fritz, and W. Schneider. 1979. The estimation of the digestibility and metabolizable energy content of ruminant feedingstuffs from the gas production when they are incubated with rumen liquor in vitro. J. Agric. Sci. 93:217-222.

Menke, K. H., and H. Steingass. 1988. Estimation of the energetic feed value obtained from chemical analysis and in vitro gas production using rumen fluid. Anim. Res. Develop. 28:78.

Minitab. 1995. Minitab Reference Manual, Release 10Xtra for Windows and Macintosh. Minitab Inc., State College, PA.

Moore, D., and I. House. 1993. Thallium poisoning. Diagnosis may be elusive but alopecia is a clue. Brit. Med. J. 306:1527-1529.

Morozzi, G., G. Cenci, and G. Caldini. 1982. The tolerance of an environmental strain of Escherichia coli to some heavy metals. Zentbl. Bakteriol. Mikrobiol. Hyg. [B] 176:55-62.

Motto, H. L., D. H. Daines, D. M. Chilko, and C. K. Motto. 1970. Lead in soils and plants: Its relationship to traffic volume and proximity to highways. Env. Sci. Tech. 4:232.

NRC. 1980. Lead in the Human Environment. National Academy of Sciences, Washington, DC.

Phillips, C. J. C. 1998. The use of individual dairy cows as replicates in the statistical analysis of their behavior at pasture (Letter to the Editor). Appl. Anim. Behav. Sci. 60:365-369.

Phillips, C. J. C. 2000. Further aspects of the use of individual animals as replicates in statistical analysis (Letter to the Editor). Appl. Anim. Behav. Sci. 69:85-88.

Phillips, C. J. C., M. Y. I. Youssef, P. C. Chiy, and D. R. Arney. 1999a. Sodium chloride supplements increase the salt appetite and reduce stereotypies in confined cattle. Anim. Sci. 68:741-748.

Phillips, C. J. C., M. Y. I. Youssef, and P. C. Chiy. 1999b. The effect of introducing timothy, cocksfoot and red fescue into a perennial ryegrass sward and the application of sodium fertilizer on the behaviour of male and female cattle. Appl. Anim. Behav. Sci. 61:215-226.

Pilgrim, W., and R. N. Hughes. 1994. Lead, cadmium, arsenic and zinc in the ecosystem surrounding a lead smelter. Env. Monit. Assess. 32:1-20.

Rind, M. I., and C. J. C. Phillips. 1999. The effects of group size on the ingestive and social behavior of grazing dairy cows. Anim. Sci. 68:589-596.

Snedecor, G. W., and W. G. Cochran. 1967. Statistical Methods. 6th ed. Iowa State University Press, Ames, Iowa.

Wainwright, M., and S. J. Grayston. 1989. Accumulation and oxidation of metal sulphides by fungi. Pages 119-130 in Metal-Microbe Interactions. RK Poole and GM Gadd, ed. IRL Press, Oxford, UK.

Ward, N. I., R. R. Brooks, and E. Roberts. 1978. Blood lead levels in sheep exposed to automotive emissions. Bull. Env. Cont. Toxic. 20:44-51. 